\title{
Finite Element Analysis of Shaba Inverted Siphon Structure
}

\author{
Liu Keding \\ Hunan Urban Construction College \\ Xiangtan, China \\ e-mail:297298755@qq.com
}

\author{
Yang Zhichao \\ Yellow River Henan Bereau \\ Zhengzhou, China \\ e-mail:yuluem@sina.com
}

\begin{abstract}
The numerical simulation study for water conveyance of inverted siphon on water security is of great significance. The inverted siphon is thin-walled concrete structure, and cracks will appear according to temperature loads. Generally speaking, the temperature difference between the internal and external and the basic difference of temperature are considered as the main factors influencing the cracks. Static analysis of inverted siphon structure is the foundation of design and construction, includes the calculation and analysis of stress and strain of inverted siphon structure. The stress and strain of inverted siphon structure not only are the index of inverted siphon structure rigidity, but also are the basis of identifying whether the inverted siphon structural damage occur. Using the basic theories of temperature and stress field of concrete, this paper adopts 3d finite element to simulate and calculate Shaba inverted siphon, and gets stress and deformation distribution of inverted siphon during operation period. The results show that inverted siphon structure is economic and reasonable, can meet the stiffness requirement, and can provide beneficial reference to the design and construction for other inverted siphon structure.
\end{abstract}

Keywords-Inverted siphon pipe; Finite element; Circumferential stress; Stiffness requirement; Operation period.

\section{INTRODUCTION}

Shaba inverted siphon project is located at Tiejia irrigation area lateral canal in the Donggou county, Liaoning province, its controlled basin area is 32200 mu.The project is designed to double hole, hole is pipe whose inner diameter is $1.0 \mathrm{~m}$, wall thickness is $0.3 \mathrm{~m}$, design discharge is $4.64 \times 2 \mathrm{~m} 3 / \mathrm{s}$. Design water level of inverted siphon project is $7.25 \mathrm{~m}$, check water level is $8.05 \mathrm{~m}$. Water flow rate of inverted siphon project is $1.48 \mathrm{~m} / \mathrm{s}$, roughness is 0.014 , head loss is $0.227 \mathrm{~m}$, total length is $84.5 \mathrm{~m}$.

\section{CAlculation Model}

\section{A. Material Parameters.}

Concrete strength grade of inverted siphon pipe is $\mathrm{C} 20$, elastic modulus of concrete is $25.5 \mathrm{GPa}$, poisson's ratio of concrete is 0.167 [1-2], bulk density is $24 \mathrm{kN} / \mathrm{m} 3$.
Foundation of inverted siphon project is marine sediments of silty loam, compression modulus is $30 \mathrm{MPa}$, poisson's ratio of concrete is $0.36[3]$.

\section{B. Element Selection and Model Size.}

When establishing structural finite element calculation model for inverted siphon pipe and foundation, we uses eight node isoparametric brick element to simulate inverted siphon pipe and foundation, and each node has three translational degrees of freedom, this elment is often applied in analysis of three-dimensional entity structure mode[4-6].

Thickness of covering for inverted siphon pipe is 1.8 $\mathrm{m}$, thickness of riverbed is $22 \mathrm{~m}$, width of river is $55 \mathrm{~m}$. The size of the whole calculation model is $85 \mathrm{~m}$ along the flow direction, $33 \mathrm{~m}$ at the transverse that is perpendicular to the flow of water, $38 \mathrm{~m}$ at the vertical that is perpendicular to the flow of water, simulation range of model is $85 \mathrm{~m} \times 33 \mathrm{~m} \times 38 \mathrm{~m}$ [7-8]. Element division of inverted siphon pipe and foundation shows in Fig.1.

\section{Calculation Cases.}

Structure analysis of Shaba inverted siphon mainly considers the following 3 kinds of calculation cases[9-10]: case 1, double hole with water and design water level $7.25 \mathrm{~m}$; case 2, double hole with water and check water level $8.05 \mathrm{~m}$; case 3 , single hole (right) with water and design water level $7.25 \mathrm{~m}$.

\section{ANALYSIS OF CALCULATION RESULTS}

\section{A. Calculation Section.}

In order to analyze stress and deformation distribution of Shaba inverted siphon under various cases, selects four calculation section that shows in Fig.2, A-A section, B-B section, C-C section and D-D section. Because symmetry of the problem , calculation section only takes part in the downstream of the inverted siphon tube hole on the right, along the flow direction. 


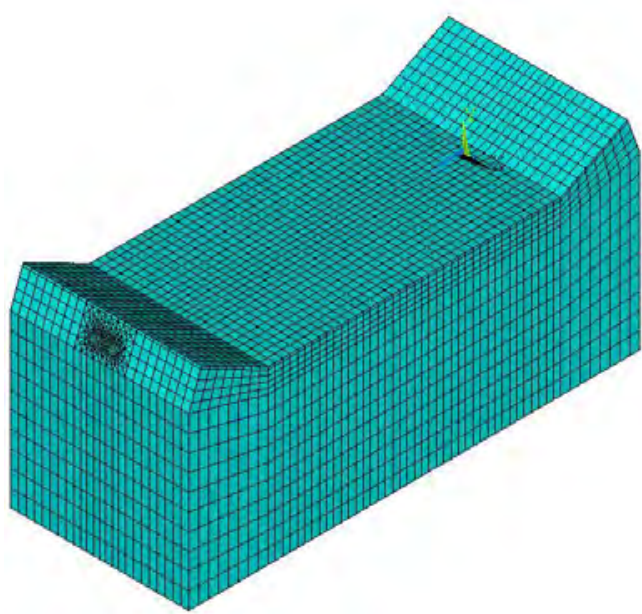

Figure 1. Element division of inverted siphon pipe and foundation

B. Stress Analysis.

Table 1 shows circumferential stress value of each key point for inverted siphon right hole, location of the

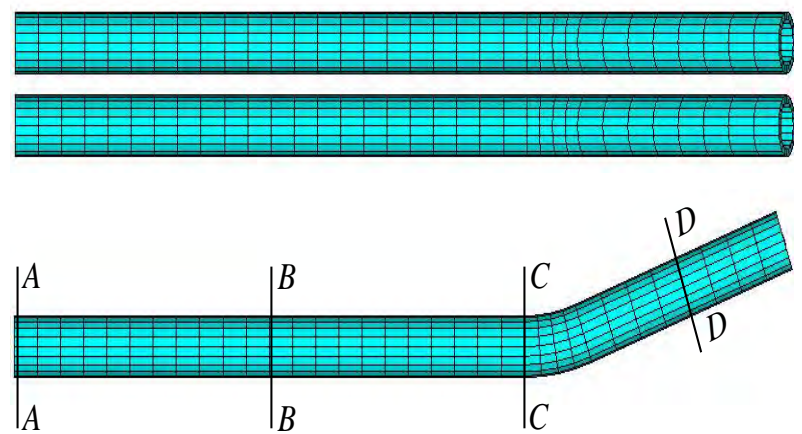

Figure 2. Element division of inverted siphon pipe and calculation section location

key points are along the flow direction every $4.5 \mathrm{~m}$, respectively in the inverted siphon pipe top, bottom and waist place on the inner surface of pipe.

Table I. STRESS VALUE OF EACH KEY POINT FOR INVERTED SIPHON RIGHT HOLE UNDER VARIOUS CASES (MPA)

\begin{tabular}{|c|c|c|c|c|c|c|c|c|c|c|c|}
\hline \multicolumn{2}{|c|}{$\begin{array}{c}\text { Location of } \\
\text { calculation point }\end{array}$} & 1 & 2 & 3 & 4 & 5 & 6 & 7 & 8 & 9 & 10 \\
\hline \multirow{4}{*}{$\begin{array}{c}\text { Case } \\
1\end{array}$} & Top of pipe & 0.27 & 0.28 & 0.29 & 0.28 & 0.26 & 0.27 & 0.27 & 0.39 & 0.42 & 0.39 \\
\cline { 2 - 11 } & $\begin{array}{c}\text { Bottom of } \\
\text { pipe }\end{array}$ & 0.40 & 0.39 & 0.40 & 0.39 & 0.39 & $0 . .39$ & 0.39 & 0.46 & 0.45 & 0.42 \\
\cline { 2 - 12 } & Waist of pipe & 0.14 & 0.12 & 0.12 & 0.13 & 0.15 & 0.14 & 0.15 & 0.04 & 0.03 & 0.02 \\
\hline \multirow{4}{*}{$\begin{array}{c}\text { Case } \\
2\end{array}$} & \begin{tabular}{c} 
Top of pipe \\
\cline { 2 - 12 }
\end{tabular} & 0.30 & 0.31 & 0.32 & 0.31 & 0.29 & 0.30 & 0.30 & 0.42 & 0.46 & 0.43 \\
\hline \multirow{2}{*}{$\begin{array}{c}\text { Base } \\
3\end{array}$} & \begin{tabular}{c} 
Waist of pipe \\
\cline { 2 - 12 }
\end{tabular} & 0.17 & 0.15 & 0.15 & 0.16 & 0.18 & 0.17 & 0.18 & 0.06 & 0.06 & 0.04 \\
\cline { 2 - 12 } & Bottom of pipe & 0.40 & 0.39 & 0.40 & 0.38 & 0.39 & 0.39 & 0.39 & 0.45 & 0.43 & 0.41 \\
\hline
\end{tabular}

As can be seen from table 1, under three kinds of cases, circumferential stress of Shaba inverted siphon is small, and circumferential stress changes little along inverted siphon axial, but circumferential stress increases at the junction of horizontal section and inclined straight section. Under various cases, circumferential stress at bottom of inverted siphon pipe

is large, circumferential stress at waist place of inverted siphon pipe is small.

Fig.3 and Fig.4 respectively show circumferential stress curve of A - A, B - B and C - C and D - D calculation section for inverted siphon under case 1 , Fig. 5 and Fig. 6 respectively show circumferential stress curve of A - A, B - B and C - C and D - D calculation section for inverted siphon under case 2 . 


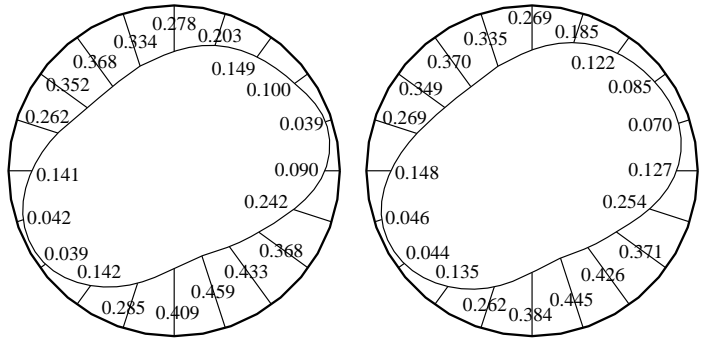

Figure 3. Circumferential stress curve of A-A and B-B section for right hole under case $1(\mathrm{MPa})$

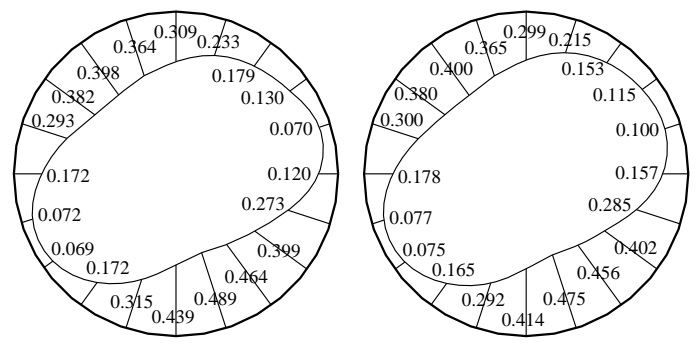

Figure 5. Circumferential stress curve of A-A and B-B section for right hole under case 2 (MPa)

As can be seen from Fig. 3 and Fig.4, under case 1 circumferential stress of inverted siphon is tensile stress basically, but small hoop compressive stress appears at waist of D-D section, and hoop tensile stress value at the top and bottom of inverted siphon is bigger, hoop tensile stress value at the waist of inverted siphon is small. This is mainly due to layer of inverted siphon at the bottom of the river is thin, horizontal stiffnes of inverted siphon based on foundation is small, which leads to hoop tensile stress at the top and bottom of inverted siphon is bigger.

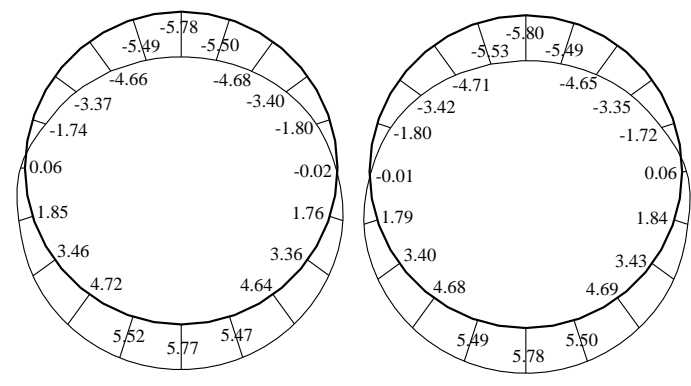

Figure 7. Radial displacement curve of A-A and C-C section for right hole under case $1(\mathrm{~m})$

As can be seen from Fig.7 and Fig.8, under case 1 and case 2 inverted siphon basically remains circular after deformation, only the vertical settlement, deformation of inverted siphon itself is very small. This is mainly due to foundation of inverted siphon is soft, its compression modulus is small, inverted siphon basically has the rigid body displacement.

\section{CONCLUSION}

In conclusion, stress and deformation value of Shaba inverted siphon during operation period is small, inverted siphon project using reinforced concrete

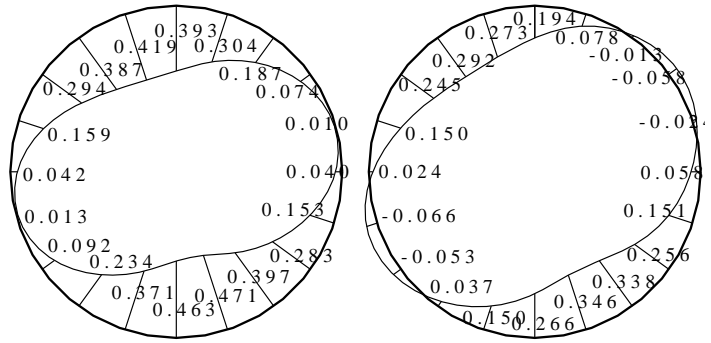

Figure 4. Circumferential stress curve of C- and D-D section for right hole under case $1(\mathrm{MPa})$

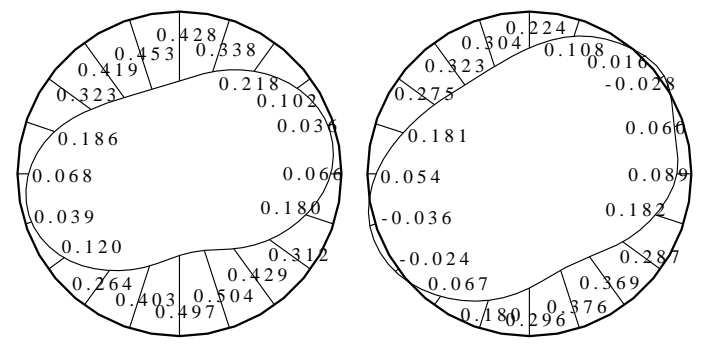

Figure 6. Circumferential stress curve of C-C and D-D section for right hole under case $2(\mathrm{MPa})$

As can be seen from Fig.5 and Fig.6, circumferential stress of inverted siphon changes rule under case 2 is similar to circumferential stress of inverted siphon changes rule under case 1 , here no longer expatiatory.

\section{DEFORMATION ANALYSIS.}

Fig.7 respectively shows radial displacement curve of $\mathrm{A}-\mathrm{A}$ and $\mathrm{C}-\mathrm{C}$ calculation section for inverted siphon under case 1, Fig.8 respectively shows radial displacement curve of $\mathrm{A}-\mathrm{A}$ and $\mathrm{C}-\mathrm{C}$ calculation section for inverted siphon under case 2 .

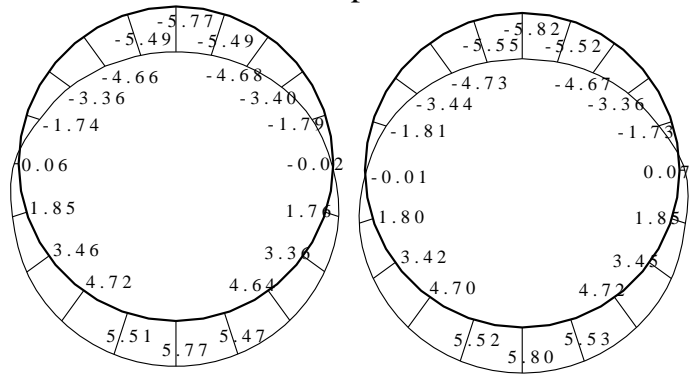

Figure 8. Radial displacement curve of A-A and C-C section for right hole under case $2(\mathrm{~m})$

structure can meet the engineering requirement and is safe and reasonable.

\section{REFERENCE}

[1] SL191-2008. Design Code for Hydraulic Concrete Structure[S]. China Water Conservancy and Hydropower Press, 2008.

[2] Xiaopei Sun,Xiaoling Wang,Ruirui Sun et al. Numerical Simulation for Water Conveyance of Inverted Siphon [C]. Advances in civil engineering II.2013:2407-2410.

[3] Juan Li,Zhenwei Mu,Lin Li et al. Numerical Simulation and Model Test on Hydraulic Characteristics of Long-Distance Inverted Siphon [C]. Advances in Hydrology and Hydraulic Engineering.2012:1112-1116. 
[4] Xucheng Wang. Finite Element Method [M]. Tsinghua University Press, 2003.

[5] Cheng Zibing,Wang Feng,Yan Wei et al. Experimental study on inverted siphon channel in South-to-North water diversion project $[\mathrm{C}]$. Advances in hydraulic physical modeling and field investigation technology.2011:685-689.

[6] Bofang Zhu. Finite Element Method Principle and Application [M]. China Water Conservancy and Hydropower Press, 1998.

[7] Shanding Ma, Ruze Wang. Hydropower Station Structures (The Second Edition) $[\mathrm{M}]$. China Water Conservancy and Hydropower Press, 1996.
[8] Wenliang Ma,Weifang Zou. Three-dimensional finite element analysis of trench-buried inverted siphon structure [C]. 2012 7th International Conference on System of Systems Engineering. $2012: 380-382$

[9] Lun-Yan Wang,Lei Guo. Analysis on Concrete's Measures for Qin river Inverted-Siphons in winter [C]. Proceedings of the third international conference on modelling and simulation. vol. 2, Modelling and simulation in engineering.2010:70-73.

[10] Huiying Li, Wenduo Tian, Haixin Yan. Inverted Siphons [M]. China Water Conservancy and Hydropower Press, 2006. 